\title{
Canadian HIV Care Settings as Patient-Centered Medical Homes (PCMHs)
}

\author{
Claire E. Kendall, MD, PhD, Esther S. Shoemaker, PhD, Janessa E. Porter, MA, \\ Lisa M. Boucher, MA, Lois Crowe, BA, Ron Rosenes, MA, LLD (hon), CM, \\ Christine Bibeau, Philip Lundrigan, Marissa L. Becker, MD, MSc, \\ Shabnam Asghari, MD, PhD, Sean B. Rourke, PhD, and Clare Liddy, MD, MSc
}

Purpose: For people living with HIV (PLWH) using continuous antiretroviral therapy, HIV is now a complex chronic condition often managed in primary care settings. The patient-centered medical home (PCMH) is a model to deliver comprehensive, coordinated, and integrated primary care that promotes collaboration between primary and specialist care and allied services. The study assessed how both Canadian primary and specialist HIV care settings align with the PCMH.

Methods: Mixed-methods surveys and interviews with providers in Canadian HIV care settings.

Results: Twenty-two settings completed the survey, 12 of which participated in follow-up interviews. Settings had a mean PCMH score of 8.06/12 (SD = 1.53), indicating the basic elements of each PCMH domain have been implemented. We found no significant differences between HIV primary care and specialist care settings. Continuous team-based healing relationships had the highest score (mean $=9.2$; SD $=2.15)$, and quality improvement strategy had the lowest score $($ mean $=7.19 ; \mathrm{SD}=2.26)$. The themes that arose from the interviews were 1) endorsement of the domains of the PCMH by all settings, 2) organizational structures of settings located in hospitals facilitating the implementation of the PCMH through existing technology, patient advisory boards, and accessible services, and 3 ) dissonance between complex care needs and existing organizational structures in some settings, including limited clinic hours, lack of electronic medical records, and limited mental health services.

Conclusions: HIV care in Canada is reasonably well aligned with the PCMH, irrespective of structure of settings. We propose the need for improvements in the use of electronic medical records, quality improvement strategies, and integration of mental health services to achieve better care delivery and health outcomes among PLWH in Canada. (J Am Board Fam Med 2019;32:158-167.)

Keywords: AIDS, Canada, Chronic Disease, Delivery of Health Care, Mental Health Services, Patient-Centered Care, Primary Health Care

Due to increased quantity and quality of life arising from combination antiretroviral therapy, HIV has evolved into a complex chronic health condition. ${ }^{1-3}$ In turn, there is a requirement to shift from a focus on treatment of opportunistic infections toward the

This article was externally peer reviewed.

Submitted 9 August 2018; revised 2 November 2018; accepted 5 November 2018.

From the CT Lamont Primary Health Care Research Centre, Bruyère Research Institute, Ottawa, Ontario, Canada (CEK, ESS, JEP, LMB, LC, RR, CB, PL, CL); Department of Family Medicine, Faculty of Medicine, University of Ottawa, Ottawa, Ontario, Canada (CEK, ESS, CL); School of Epidemiology and Public Health, Faculty of Medicine, University of Ottawa, Ottawa, Ontario, Canada (CEK, LMB); Department of Family and Community Medicine, prevention and management of multimorbidity ${ }^{4}$ among people living with HIV (PLWH). This shift reinforces the importance of meeting the compre-

Li Ka Shing Knowledge Institute, St. Michael's Hospital, Toronto, Ontario, Canada (CEK, ESS); Ottawa Hospital Research Institute, Ottawa, Ontario, Canada (CEK); Departments of Medicine, Medical Microbiology and Community Health Sciences, University of Manitoba, Winnipeg, Manitoba, Canada (MLB); Department of Family Medicine, Centre for Rural Health Studies, Memorial University of Newfoundland, St. John's, Newfoundland, Canada (SA); Department of Psychiatry, University of Toronto, Toronto, Ontario, Canada (SBR); Centre for Urban Health Solutions, Li Ka Shing Knowledge Institute, St. Michael's Hospital, Toronto, Ontario, Canada (SBR).

Funding: The study was funded by the Canadian Institutes of Health Research (CIHR) FRN TT5-128270. 
hensive, continuous care needs of PLWH while promoting the integration of primary care with other medical specialties. ${ }^{5}$ Physicians specialized in $\mathrm{HIV}$ or infectious diseases predominately manage the care of PLWH in Canada, ${ }^{6}$ and while they are best equipped to deliver disease-specific care, ${ }^{7}$ primary care providers have the expertise to deliver chronic disease care. ${ }^{8}$ Canadian HIV primary care settings are more likely to offer preventative health services than specialist care settings. ${ }^{9}$ Currently, we know little about how the evolving needs of $\mathrm{PLWH}$ are met within the settings where they receive care.

The patient-centered medical home (PCMH) is an approach to transforming primary care delivery through improving its quality, effectiveness, and efficiency, thereby facilitating its role as the foundation of a high-performing health system. ${ }^{10}$ The joint domains of the PCMH (Table 1) have the potential to address existing care gaps through integration and collaboration between primary and specialist care, community health and social services. ${ }^{11}$ The Ryan White-funded HIV clinics became early adopters of the PCMH model ${ }^{12}$ that has since become the standard for primary care delivery. ${ }^{13-15}$ A recent study of HIV clinics within the Veterans Affairs Health System found variation in the alignment of HIV specialty clinics to PCMH principles. ${ }^{16}$ Our objective was to determine the alignment of Canadian HIV care settings, which vary considerably in structure, function, and team composition, ${ }^{9}$ to the PCMH. As all Canadian provinces have a single-payer system with universal access to physician services, our findings can inform recommendations to ensure $\mathrm{PLWH}$ receive patient-centered care in a setting and with providers appropriate to their evolving physical, mental, cognitive, and social needs.

\section{Methods}

\section{Study Design}

We conducted an explanatory sequential mixedmethods study, which included a Web-based survey between June 2015 and January 2016 followed

Conflict of interest: none declared.

Disclaimer: The authors are solely responsible for the content of the article.

Corresponding author: Claire E. Kendall, $\mathrm{MD}, \mathrm{PhD}$, Department of Family Medicine, University of Ottawa, 43 Bruyère St, Annex E, Ottawa, ON, K1N 5C8, Canada (E-mail: ckendall@uottawa.ca). by semistructured interviews between November 2016 and February 2017. The survey was used to evaluate the alignment of HIV care settings with the PCMH, while the interviews with a sample of the survey respondents were conducted to further explain the results from the survey and to assess in greater detail if and how settings implement the joint domains of patient oriented care as specified by the $\mathrm{PCMH}$.

\section{Setting and Participants}

The study is part of a large Canadian Institutes of Health Research funded team grant (https:// www.lhiv.ca/). Appendix A outlines our sampling strategy. We identified Canadian HIV care settings using purposive sampling of potential settings based on an environmental scan and expert knowledge of team members. We recruited key contact persons at these settings via phone and invited them to participate. We included settings with an identified focus on providing care to PLWH, but did not restrict our search based on proportion of patients with HIV or on whether services were provided to an HIV priority population, such as men who have sex with men. Survey participants were asked for consent to be contacted for a follow-up interview. Interview participants received a $\$ 75$ gift card.

\section{Theoretical Framework}

Our research was guided by the PCMH framework including 8 evidence-based domains that were specifically developed to guide settings that intend to become a $\mathrm{PCMH}^{17}$ (Table 1). The domains define the characteristics and behaviors that constitute a $\mathrm{PCMH}$, enabling our team to assess the individual setting's level of alignment with each of the 8 domains.

\section{Measurements}

We developed the Canadian HIV Clinic Survey, which included an adaptation of 2 validated primary health care surveys, the Patient-Centered Medical Home Assessment (PCMH-A) ${ }^{10,13}$ and the Canadian Institutes of Health Information Organizational Attributes of Primary Health Care Survey. ${ }^{18}$ The PCMH-A tool was developed for care settings to assess their alignment to the PCMH model. ${ }^{19}$ Each domain is scored on a 12-point scale, with total scores associated with a level and corresponding interpretation (Table 2).We modi- 
Table 1. Domains of the PCMH Framework

\begin{tabular}{|c|c|}
\hline Domain & Definition \\
\hline 1: Patient rostering & $\begin{array}{l}\text { Patients are assigned to specific providers and care teams. } \\
\text { Patient data is routinely used for scheduling purposes and monitored to balance } \\
\text { supply and demand. } \\
\text { Electronic medical records on individual patients are available to practice } \\
\text { teams. } \\
\text { Reports on care processes are provided. }\end{array}$ \\
\hline 2: Continuous, team-based healing relationships & $\begin{array}{l}\text { Patient sees their own provider or team. } \\
\text { Non-physician practice team members perform key clinical service roles that } \\
\text { match their ability and credentials. } \\
\text { Staff is properly trained for roles and responsibilities. }\end{array}$ \\
\hline 3: Patient-centered interactions & $\begin{array}{l}\text { Patients are driving their care. } \\
\text { Patient and family values and preferences are assessed and incorporated in } \\
\text { planning and organizing care. } \\
\text { Communication techniques are used, such as translation services, to ensure the } \\
\text { patient can understand. } \\
\text { Self-management support is provided. } \\
\text { Patient-centeredness is consistently used to guide organizational changes. } \\
\text { Frequent and actionable input from patients and family members is used for } \\
\text { quality improvement. }\end{array}$ \\
\hline 4: Engaged leadership & $\begin{array}{l}\text { Leaders support continuous learning, review and act upon quality data, and } \\
\text { have long-term strategy and funding commitment to explore and implement } \\
\text { change. } \\
\text { Clinical leaders champion and engage clinical teams in improving patient } \\
\text { experience of care and clinical outcomes. } \\
\text { Hiring and training supports and sustain improvements. } \\
\text { Responsibility for quality improvement activities is shared by staff, and time is } \\
\text { protected to meet to engage in quality improvement. }\end{array}$ \\
\hline 5: Quality improvement strategy & $\begin{array}{l}\text { Electronic health record and other health information technology used to } \\
\text { support population management and quality improvement efforts. } \\
\text { Feedback provided to care teams and staff to improve processes and outcomes. } \\
\text { Performance measurement is used and reported back to providers. }\end{array}$ \\
\hline 6: Enhanced access & $\begin{array}{l}\text { Appointments are flexible and can accommodate customized visit lengths, same- } \\
\text { day visits, and scheduled follow-up. } \\
\text { Choice of phone, e-mail to contact the practice team during normal hours. } \\
\text { After-hours access is available. } \\
\text { Enhanced access includes eliminating barriers to care including those related to } \\
\text { a patient's ability to pay. }\end{array}$ \\
\hline 7: Care coordination & $\begin{array}{l}\text { Care coordinated within practice, creating a care hub, and between the practice } \\
\text { and outside services. } \\
\text { Team reaches out and connects in meaningful ways with other sources of } \\
\text { service, and communicates consistently and without delay. }\end{array}$ \\
\hline 8: Organized, evidence-based care & $\begin{array}{l}\text { Guideline based care that incorporates preventative and chronic illness needs. } \\
\text { Visits are organized to address both acute and planned care needs. } \\
\text { Case managers are available, and used for high risk patients. } \\
\text { Care plans are developed collaboratively, including clinical management. }\end{array}$ \\
\hline
\end{tabular}

PCMH, patient-centered medical home.

fied the PCMH to ensure relevance to the Canadian health care system while leaving the scoring system unchanged.

After survey analysis, the team reviewed the data and developed an interview guide to further assess the implementation of the patient-oriented aspects of the PCMH. Two interviewers conducted semi- structured interviews over the phone with physicians, nurses, and others in leadership positions at 12 of the 22 surveyed settings. Interviews included questions about the services offered, the setting's approach to patient-centered care, and the involvement of senior management. Interviews were recorded and transcribed verbatim. 
Table 2. Interpretation of PCMH-A Scores

\begin{tabular}{ll}
\hline Score & Level \\
\hline $\begin{array}{l}10 \text { to } 12 \\
7 \text { to } 9\end{array}$ & B $\quad \begin{array}{l}\text { Most or all of the critical aspects of the key change addressed by the item are well established in the practice. } \\
\text { The basic elements of the key change have been implemented, although the practice still has significant } \\
\text { opportunities to make progress with regard to one or more important aspects of the key change. }\end{array}$ \\
4 to 6 & C $\begin{array}{l}\text { The first stage of implementing a key change may be in place, but that important fundamental changes have } \\
\text { yet to be made. }\end{array}$
\end{tabular}

PCMH-A, patient-centered medical home assessment.

Source: http://www.safetynetmedicalhome.org/sites/default/files/PCMH-A.pdf.

\section{Analysis}

To analyze the survey responses, we categorized settings into 2 groups: clinics containing either a family practitioner or a nurse practitioner (primary care settings, $\mathrm{n}=12$ ) and settings containing only an infectious diseases specialist (specialist care settings, $\mathrm{n}=10$ ). We calculated the mean and standard deviation to assess settings' PCMH scores and used 2-tailed independent samples $t$-tests to assess differences in scores between the groups.

Interviews were analyzed by 2 reviewers using the coding framework approach for qualitative data analysis. ${ }^{20}$ The goal of the analysis was to assess how settings interpreted the patient oriented aspect of the PCMH and how settings perceived their care practices to align with the PCMH. A thematic framework was constructed based on the definitions of the 8 domains of the PCMH, and in direct correspondence with the survey. The data were coded to identify elements confirming and disconfirming alignment with the PCMH, to compare the answers of providers from primary care and specialist care settings, and to compare between settings with lower and higher PCMH alignment. The reviewers met weekly to compare and discuss their findings, which were shared with collaborators, including $3 \mathrm{PLWH}$, who helped interpret the results and to derive at the themes that helped contextualize the quantitative survey results. In addition, as with all studies on our team, ${ }^{21} \mathrm{PLWH}$ collaborators participated in the development of the research questions, the initial design of the research and the creation of the interview guide. They were consulted about the relevance of the research findings to the lives of PLWH. They, for example, highlighted the role of technology and the associated advantages and disadvantaged of a functioning EMR system. NVivo 11 was used for analysis. $^{22}$ The ethics boards of the Ottawa Health
Sciences Network (protocol \#20140649 a - 01H) and Bruyère Continuing Care (protocol \#M16 a 15 a - 011) approved the study.

\section{Role of the Funding Source}

The study was funded by the Canadian Institutes of Health Research (CIHR) FRN TT5 a - 128270. CIHR had no role in the design of the study, the collection, analysis, and interpretation of the data, and the reporting of the findings.

\section{Results \\ Background Information of Participating HIV Care Settings}

Twenty-two care settings completed the survey (response rate of 51\%): 20 in English, 2 in French. Sixteen of the 22 surveyed settings ( $73 \%$ ) consented to be contacted for follow-up interviews, and 12 of the $16(75 \%)$ were interviewed. The details of the organizational attributes of the settings are provided elsewhere. ${ }^{9}$ Most Canadian HIV care settings were located in urban settings (19/22 in a city) and 15/22 care settings were located within a hospital. Twelve settings were defined as primary care and 10 as specialist care settings.

\section{Alignment with the PCMH}

The mean PCMH-A score of the settings surveyed was $8.06(\mathrm{SD}=1.53)$ out of a possible 12 points, indicating that the "basic elements" of each domain have been implemented. There were no significant differences between primary care and specialist care settings across either mean or individual PCMH domain scores (Table 3). Two settings scored in level A, representing higher alignment with the $\mathrm{PCMH}$ and providing patient-centered care, and 5 settings scored in level $\mathrm{C}$, representing lower alignment with the PCMH and offering only basic sup- 
Table 3. PCMH-A Scores of Primary and Specialist Canadian HIV Care Settings by Type of Care Settings and Interpretation

\begin{tabular}{|c|c|c|c|c|c|c|c|}
\hline \multirow[b]{2}{*}{ Domain } & \multicolumn{2}{|c|}{$\begin{array}{l}\text { Primary Care } \\
\quad(\mathrm{n}=12)\end{array}$} & \multicolumn{2}{|c|}{$\begin{array}{l}\text { Specialist Care } \\
\quad(\mathrm{n}=10)\end{array}$} & \multicolumn{2}{|c|}{ Interpretation } & \multirow{2}{*}{$\begin{array}{c}P \text {-Values for } \\
t \text {-Test }\end{array}$} \\
\hline & Mean & SD & Mean & $\mathrm{SD}$ & Mean Score (/12) & Level (A-D) & \\
\hline 1: Patient rostering & 7.98 & 2.26 & 8.53 & 2.46 & 8.23 & B & .594 \\
\hline 2: Team-based relationships & 8.61 & 2.04 & 9.92 & 2.15 & 9.20 & B & .160 \\
\hline 3: Patient-centered interactions & 7.35 & 1.82 & 8.53 & 2.49 & 7.89 & B & .213 \\
\hline 4: Engaged leadership & 8.02 & 2.09 & 8.19 & 2.63 & 8.10 & B & .866 \\
\hline 5: Quality improvement & 7.31 & 2.25 & 7.05 & 2.39 & 7.19 & B & .794 \\
\hline 6: Enhanced access & 8.11 & 2.35 & 6.53 & 2.40 & 7.39 & B & .136 \\
\hline 7: Care coordination & 8.49 & 1.43 & 8.24 & 2.04 & 8.37 & B & .743 \\
\hline 8: Evidence-based care & 8.07 & 2.03 & 8.13 & 2.47 & 8.09 & B & .954 \\
\hline Total & 7.99 & 1.36 & 8.14 & 1.79 & 8.06 & B & .831 \\
\hline
\end{tabular}

PCMH-A, patient-centered medical home assessment; SD, standard deviation.

port for patient-centered care. There were no significant differences in mean PCMH total score and individual domain scores between survey respondents who did and did not consent to be interviewed.

\section{Rostering}

Rostering refers to the assignment of individual patients to specific providers and forms the basis for continuity of care and population health management. The mean score for patient rostering was 8.23 ( $\mathrm{SD}=2.31)$ reflecting that most patients are registered with a particular provider but that improvements can be made by using electronic medical records (EMRs) to support care. Most (10/12) interview participants described that patients are assigned to a specific provider, "so the patient will always know who their nurse is or who to contact if they have issues" (setting (S) 7). In contrast, 2 participants explained that the care of all their patients is shared between providers. Although participants recognized their importance, the availability and uptake of EMR as a tool for rostering and population planning was limited, "[The EMR is] not great in terms of us being able to track CD4 or viral loads" (S9). Participants without EMR (4/12) expressed frustration about not having access to these data, and 1 explained that concern for privacy breaches inhibited them from making patient data accessible electronically.

\section{Continuous, Team-Based Healing Relationships}

Continuous, team-based healing relationships includes encouraging patients to see their own pro- vider, nonphysician providers being able to perform important clinical roles, and the provision of training as required by staff. It was the highest-scoring domain with a mean of 9.2 (SD = 2.15) illustrating that the continuous care approach is well integrated in Canadian HIV care settings. Interview participants described working as large and well-integrated teams where patients were oriented to all team members: "They are always introduced to our social workers, even if they do not need anything at that time. At least they bave a name and a face and a card so if there are issues down the road. And then introduce them to any other team members that they might need" (S1). In contrast, 1 setting with lower PCMH alignment explained that their team only consists of infectious disease specialists.

An important premise of a PCMH is that team members work to their full scope of practice. ${ }^{24}$ One participant described ensuring their staff received training that enabled them to care for complex clients, "A lot of our staff are trained in motivational interviewing and [...] have those skill sets to move people or start to engage people in terms of health goals" (S9). While scores were high across settings, we identified limitations in the implementation of this domain. For example, the roles of individual clinicians within settings were not always clearly delineated, "Sometimes I am the social worker even though I am not trained. Sometimes the social worker is the nurse practitioner a little bit" (S4). In addition, some settings reported that continuous care is compromised due to high staff turnover. 


\section{Patient-Centered Interactions}

The domain patient-centered interactions include a systematic assessment of patient's values and preferences, encouragement of and support for shared decision making and the provision of self-management support services. Settings had a patient-centered interactions score of $7.89(\mathrm{SD}=2.18)$ showing that settings generally respected patients' values, supported shared decision making and elicited patients' feedback. Interview participants were able to define the concept well even in instances where they reported struggling to implement such care in practice. One participant from a setting with lower PCMH alignment described a patient-centered setting as "a clinic that offers care to clients who have, with HIV. It is a clinic that can respond to needs, say, from Monday to Friday with a sort of walk-in approach where patients can be seen, can get information. In addition, it is a place where patients can be followed by a multidisciplinary team that can include at times a doctor, a nurse, a pharmacist, a social worker precisely to organize many, many different orientations of this, treatment of this clientele, which goes way beyond $H I V$, of course. It can be work-related problems, insurance, bealth insurance, employment, other conditions, other associated comorbidities" (S12). However, they then reported, "For us, our clinic is not such a clinic." Some participants explained that limited consultation time inhibits a patient-centered approach, while others said their staff may not be sufficiently trained to provide patient-centered care.

All participants described the importance of patient-centered care, "When we first meet with the family and patient we describe to them what our clinic, how our clinic functions [...], help them be part of the decision making of when starting medication or we need to know more about the family dynamics and if there's issues that would be roadblocks to treatment. So I think it is always approaching the family as they are part of the team" (S8). Multiple settings (5/12) facilitated patient-centeredness using translation services, including access to American Sign Language.

All settings elicited patient feedback through surveys and 3 settings involved community members as representatives on patient advisory boards, a system that had been implemented at their affiliated hospital. Participants from settings with lower PCMH alignment were concerned about the limited input patients have regarding organizational decisions, "In terms of leadership and decision making, we need more patient input as well" (S10).

\section{Engaged Leadership}

Engaged leadership incorporates supportive executive and clinical leaders who support the implementation of PCMH principles. Settings had a mean engaged leadership score of 8.10 (SD = 2.30), indicating generally a shared vision of staff and management for the PCMH model of care and their systematic collaboration to provide best care for patients. Many participants (7/12) described working in a supportive environment where management understands the principles of patient-centered care and leaders are engaged and listen to needs of front-line staff. One setting with higher $\mathrm{PCMH}$ alignment explained that, as a community health center, the tenets of patient-centered care were embedded in their operations. Five settings (4 of which had lower PCMH alignment) described their leaders as disengaged, related to the care setting being located within a larger hospital, "It is a big hospital so, the big changes we do not find out about, [...] they are made outside of our realm" (S1). Participants reported that hospital leadership may not fully understand the complexities of HIV care when making budget or staff decisions, thus risked implementing changes without adequate consultation.

\section{Quality Improvement Strategy}

This domain refers to the implementation and measurement of activities that are meant to improve care quality and patients' experiences and health information technology is an important component. Quality improvement strategy had the lowest mean score of $7.19(\mathrm{SD}=2.26)$ and the 5 settings with lower PCMH alignment had particularly low scores (range, 3.67 to 5.5) in this domain, reflecting that settings initiated quality improvement activities, but they often did not measure the outcomes of such activities. Settings with higher PCMH alignment described using surveys to collect data on patients' experiences, "We survey every year to make sure that we are meeting the needs of our patients and our clients. [...] And we try to make changes accordingly whenever we possibly can" (S1), but they did not describe how the findings were used to implement organizational change. Another participant shared that their setting routinely assesses its policies and procedures using an externally administered survey. However, as described, uptake of EMR for quality improvement was limited in most settings. 


\section{Enhanced Access}

Enhanced access corresponds to the elimination of barriers for patients to access care, including time, place, and cost of care. Settings had a mean enhanced access score of $7.39(\mathrm{SD}=2.45)$, reflecting a perceived ability to provide patients with flexible and affordable access to care, services, and advice around the clock. Six settings had limited times for patient visits because their services were bound by hospital hours. One of those settings, with higher PCMH alignment, compensated by providing telephone access between in-person appointments, "We have business cards that we give them if there's any issues or side effects that they experience" (S1). To enhance geographic reach, videoconferencing access was offered at 2 settings, and 2 other settings provided patients with flexible hours including evening and weekend, "because we all share the same electronic medical record, if let us say a person with HIV ran out of their antiretrovirals and it is Sunday, from noon to 4 they could go to 1 of our 6 sites" (S4). Participants from all settings described having pharmacists or social workers with the expertise to help patients navigate the various potential funding schemes for affordable HIV medication access.

\section{Care Coordination}

Care coordination refers to the appropriate allocation of care services within settings and communities. Settings had a mean care coordination score of 8.37 ( $\mathrm{SD}=1.69)$, indicating patient care is organized reasonably effectively. Interview participants explained in great detail the relationships they have fostered among providers within their settings and communities to care for their patients' complex needs. Eleven settings coordinated extensive services beyond HIV-specific care. Participants from several settings outlined the need for their patients to have a primary care provider who will coordinate the person's care, "We are specialists. [...] We're seeing the patient, we're following the patient for the $H I V$. But we depend on the primary care doctors to follow on a regular basis" (S6). A participants from a setting with lower PCMH alignment described visit length being too short for specialists to properly manage all the needs of their patients. To greater meet their patients' needs, this setting employed a social worker and a case manager to coordinate required care and social services for their patients within the community, while other settings employed "nurse practitioners who provide primary care services" (S9). All interview participants described a need for more mental health services, including trauma and addiction services, which were either not available or not available in a timely fashion for all patients either in the care setting or the community. Finally, use of an EMR was described as being important for intraclinic communication and collaboration around individual patients, "Our director of the HIV program also has access to our EMR so that we can consult him through the EMR and he'll respond with, to do a chart review. And give us that expert advice" (S3).

\section{Organized, Evidence-Based Care}

Organized, evidence-based care includes the use of guideline-based information when making care decisions to meet patients' acute, preventative, and chronic care needs and to ensure follow-up care. Settings had a mean of $8.09(\mathrm{SD}=2.19)$ in this domain, reflecting care is generally structured to meet both urgent and preventative needs and highrisk patients are identified; however, settings' scores varied considerably. Several participants described using practice data to address the complex needs of their patients. A participant from a setting with higher $\mathrm{PCMH}$ alignment spoke about the role of case managers, who they involved in the development of care plans, "provincially, there's been a lot of success around case management and a lot of our patients simply would not be engaged in care if they did not have case management" (S10). One participant described using the data collected with the EMR effectively to apply evidence-based strategies to care for their patients, "We stratify then by CD4 counts. So we can sort of prioritize those patients who are at highest risk of getting sick" (S3). Based on the EMR reports, the nurse and physician will collaborate with social workers to create care plans.

\section{Discussion}

Our analysis has 3 important findings that advance our understanding of the alignment of Canadian HIV care settings with the PCMH. First, all HIV care settings interviewed endorse the domains of $\mathrm{PCMH}$, irrespective of their composition. While a study in the US found that traditional specialist consultation models struggled to implement the principles of the $\mathrm{PCMH},{ }^{16}$ we found no differences between specialty and primary HIV care settings in their alignment to the PCMH model. At the start 
of the epidemic, HIV care was interdisciplinary out of necessity, with specialists collaborating with primary care and other providers to improve patients' quality of life. ${ }^{5,24}$ This grassroots collaboration could explain the similarities we found between primary and specialist care settings and the recognition among interviewed participants from specialist settings of the importance of connecting their patients to primary care. While the $\mathrm{PCMH}$ was envisioned for primary care transformation, there is recognition for the need of implementing PCMH domains in specialist care settings and Infectious disease participants understood the need for patient-centered HIV care. Fix et $\mathrm{al}^{16}$ noted that a specialist consultative model poses a risk to PCMH-principled care and our research shows that they can align well with the PCMH when collaborating and communicating closely with primary care by establishing relationships with primary care settings. In addition, all settings strongly endorsed team-based care and interdisciplinary collaboration, consistent with care models for people with other chronic conditions. ${ }^{25}$ Few settings delivered complete enhanced access to care, but settings mitigated this by offering after-hour telephone services, telemedicine and by connecting patients to primary care physicians. Settings also ensured their patients have access to affordable medications, which remains a gap for PLWH in Canada despite our universal access to physician services. ${ }^{26}$ In addition, all participants reported on the importance of incorporating the patient perspective into how care is delivered within their settings. ${ }^{27}$

Second, our results reflect that existing organizational structures of care settings located in larger institutions can help facilitate the implementation of PCMH domains. Despite structural variation, overall, settings leveraged existing resources such as established patient advisory boards, EMR and technology, ${ }^{15}$ including telemedicine and translation services. Larger organizations are further more likely to have established protocols for care coordination, ${ }^{15}$ which was noted by participants to be required to address the clinical complexity of HIV care.

Third, we found that some settings experienced dissonance between the complex needs of their patients and existing organizational structures and rigid organizational policies. Even though a number of settings had EMR, some struggled with us- ing EMR to fulfill PCMH domains. For example, participants expressed challenges in using the EMR as a clinical information system for population management, to implement decision support, or to facilitate communicate with other providers. The inhibited use of EMR due to rigid policies limited the ability of setting to measure and achieving cascade goals, and modification to existing EMR systems may be needed to fully meet the needs of the population. ${ }^{28}$ In addition, limited clinic hours were described as a barrier for care access, despite afterhours access being increasingly recognized as important for high-quality care. ${ }^{29}$ The lack of mental health services within settings was particularly daunting for participants. There is a high burden of mental health and addiction for $\mathrm{PLWH}^{30}$ and increasingly large wait times for mental health services were noted in the interviews. While not specifically prompted, none of the participants described comprehensive quality improvement strategies, despite the increasing emphasis on quality improvement in health systems practices. ${ }^{31,32}$

We acknowledge limitations in our study. Settings in some provinces did not participate, limiting the generalizability of our findings. The participating settings were predominately in urban areas, potential due to challenges in access to specialty care services in rural areas, ${ }^{33}$ where sites may not promote themselves as HIV care settings. Our data are based on self report, thus response bias is anticipated. While the PCMH can serve as a framework to assess change in the quality of care over time, we intentionally adopted it as a theoretical framework to highlights how settings align with the $\mathrm{PCMH}$ and where there is a need for improvement at 1 point in time. Finally, while we include people with lived experience as coauthors on this project, $\mathrm{PCMH}$ scores and interviews were obtained from care teams, which may not reflect the patient experience of care.

In conclusion, Canadian HIV care settings were highly committed to the domains of patient-centered care, but implementation of the PCMH was at times limited by organizational structures and processes. Lessons learned from our analysis are the need for improvements in the use of technology to improve population management and quality improvement strategies, as well as accessible mental health services to achieve better care delivery and health outcomes among PLWH. 
We thank the participants who generously donated their time and filled out the survey and answered our interview questions. We are grateful to Naomi Tschirhart and Danielle Rolfe who conducted the interviews.

To see this article online, please go to: http://jabfm.org/content/ 32/2/158.full.

\section{References}

1. Kuehn B. Physicians focus on primary care for patients with HIV. JAMA 2014;311:17-8.

2. Greene M, Justice AC, Lampiris HW, Valcour V. Management of human immunodeficiency virus infection in advanced age. JAMA 2013;309:1397-1405.

3. Siddiqi AA, Hall HI, Hu X, Song R. Populationbased estimates of life expectancy after HIV diagnosis. United States 2008-2011. J Acquir Immune Defic Syndr 2016;72:230-236.

4. Cooper V, Clatworthy J, Youssef E, et al. Which aspects of health care are most valued by people living with $\mathrm{HIV}$ in high-income countries? A systematic review. BMC Health Serv Res 2016;16:677.

5. Boyd CM, Lucas GM. Patient-centered care for people living with multimorbidity. Curr Opin HIV AIDS 2014;9:419-427.

6. Guenter D, Scott S. Short report: Canadian family doctors caring for people with HIV and AIDS. Canada's National Family Physician Workforce Survey. Can Fam Physician 2004;50:1011-1013.

7. Kendall CE, Taljaard M, Younger J, Hogg W, Glazier RH, Manuel DG. A population-based study comparing patterns of care delivery on the quality of care for persons living with $\mathrm{HIV}$ in Ontario. BMJ Open 2015;5(5):e007428.

8. Stange KC, Ferrer RL. The paradox of primary care. Ann Fam Med 2009;7:293-299.

9. Kendall CE, Shoemaker ES, Boucher LM, et al. The organizational attributes of HIV care delivery models in Canada: A cross-sectional study. PLoS One 2018;13(6): 0199395.

10. Stange KC, Nutting PA, Miller WL, et al. Defining and measuring the patient-centered medical home. J Gen Intern Med 2010;25:601-612.

11. Gallant JE, Adimora AA, Carmichael JK, et al. Essential components of effective HIV care: A policy paper of the HIV medicine association of the infectious diseases society of america and the ryan white medical providers coalition. Clin Infect Dis 2011;53: 1043-1050.

12. Saag MS. Ryan White: An unintentional home builder. AIDS Read 2009;19:166-168.

13. The College of Family Physicians of Canada. Family Practice The Patient's Medical Home A Vision for Canada. Ottawa, ON; 2011. Available from: http:// www.cfpc.ca/uploadedFiles/Resources/Resource_Items/ PMH_A_Vision_for_Canada.pdf.

14. Schoen C, Osborn R, Squires D, Doty M, Pierson R, Applebaum S. New 2011 survey of patients with complex care needs in eleven countries finds that care is often poorly coordinated. Health Aff 2011; 30:2437-2448.

15. Pappas G, Yujiang J, Seiler N, et al. Perspectives on the role of patient-centered medical homes in HIV Care. Am J Public Health 2014;104(7):e49-e53.

16. Fix GM, Asch SM, Saifu HN, Fletcher MD, Gifford AL, Bokhour BG. Delivering PACT-principled care: Are specialty care patients being left behind? J Gen Intern Med 2014;29(Suppl 2):S695-S702.

17. Wagner EH, Coleman K, Reid RJ, Phillips K, Abrams MK, Sugarman JR. The changes involved in patient-centered medical home transformation. Prim Care 2012;39:241-259.

18. Canadian Institute for Health Information. Measuring organizational attributes of primary health care survey. Available from: https://www.cihi.ca/sites/ default/files/info_phc_organize_en.pdf.

19. Daniel DM, Wagner EH, Coleman K, et al. Assessing progress toward becoming a patient-centered medical home: An assessment tool for practice transformation. Health Serv Res 2013;48(6 Pt 1):1879_ 1897.

20. Ritchie J, Lewis J, McNaughton Nicholls C, Ormston R. Qualitative Research Practice: A Guide for Social Science Students and Researchers. 2nd ed. Thousand Oaks, CA: SAGE Publications Inc; 2013.

21. Kendall CE, Shoemaker ES, Crowe L, et al. Engagement of people with lived experience in primary care research: the Living with HIV (LHIV) Innovation Team Community Scholar Program. Can Fam Physician 2017;63:730-731.

22. QSR International Pty Ltd. NVivo qualitative data analysis Software. 2013.

23. Patel MS, Arron MJ, Sinsky TA, et al. Estimating the staffing infrastructure for a patient-centered medical home. Am J Manag Care 2013;19:509-516.

24. Rodriguez HP, Marsden PV, Landon BE, Wilson IB, Cleary PD. The effect of care team composition on the quality of HIV care. Med Care Res Rev 2008;65:88-113.

25. Cheever LW, Lubinski C, Horberg M, Steinberg JL. Ensuring access to treatment for HIV infection. Clin Infect Dis 2007;45(Suppl 4):S266-S274.

26. Kaposy C, Greenspan NR, Marshall Z, Allison J, Marshall S, Kitson C. The ethical case for providing cost-free access to lifesaving HIV medications in Canada. Healthc Manage Forum 2016;29:255-259.

27. Santana MJ, Manalili K, Jolley RJ, Zelinsky S, Quan $\mathrm{H}, \mathrm{Lu}$ M. How to practice person-centred care: A conceptual framework. Heal Expect 2018;21:429440.

28. O'Malley AS, Grossman JM, Cohen GR, Kemper NM, Pham HH. Are Electronic Medical Records Helpful for Care Coordination? Experiences of Physician Practices. J Gen Intern Med. 2010;25:177185. 
29. Johnston S, Hogel M, Burchell AN, et al. Developing a performance framework for measuring comprehensive, community-based primary healthcare for people with HIV. Prim Health Care Res Dev 2015: $1-24$.

30. Durbin A, Brown HK, Antoniou T, et al. Mental health disorders and publicly funded service use by HIV positive individuals: A population-based crosssectional study in Ontario, Canada. AIDS Behav 2017;21:3457-3463.
31. Martin LT, Plough A, Carman KG, Leviton L, Miller CE, Miller CE. Strengthening integration of health services and systems. Health Aff (Millwood) 2016;35:1976-1981.

32. Hutchison B. Reforming Canadian primary careDon't stop half-way. Healthc policy 2013;9:12-25.

33. Wilson LE, Korthuis T, Fleishman JA, et al. HIVrelated medical service use by rural/urban residents: A multistate perspective. AIDS Care 2011;23:971979. 


\section{Appendix A}

Flow Chart of Sampling Strategy

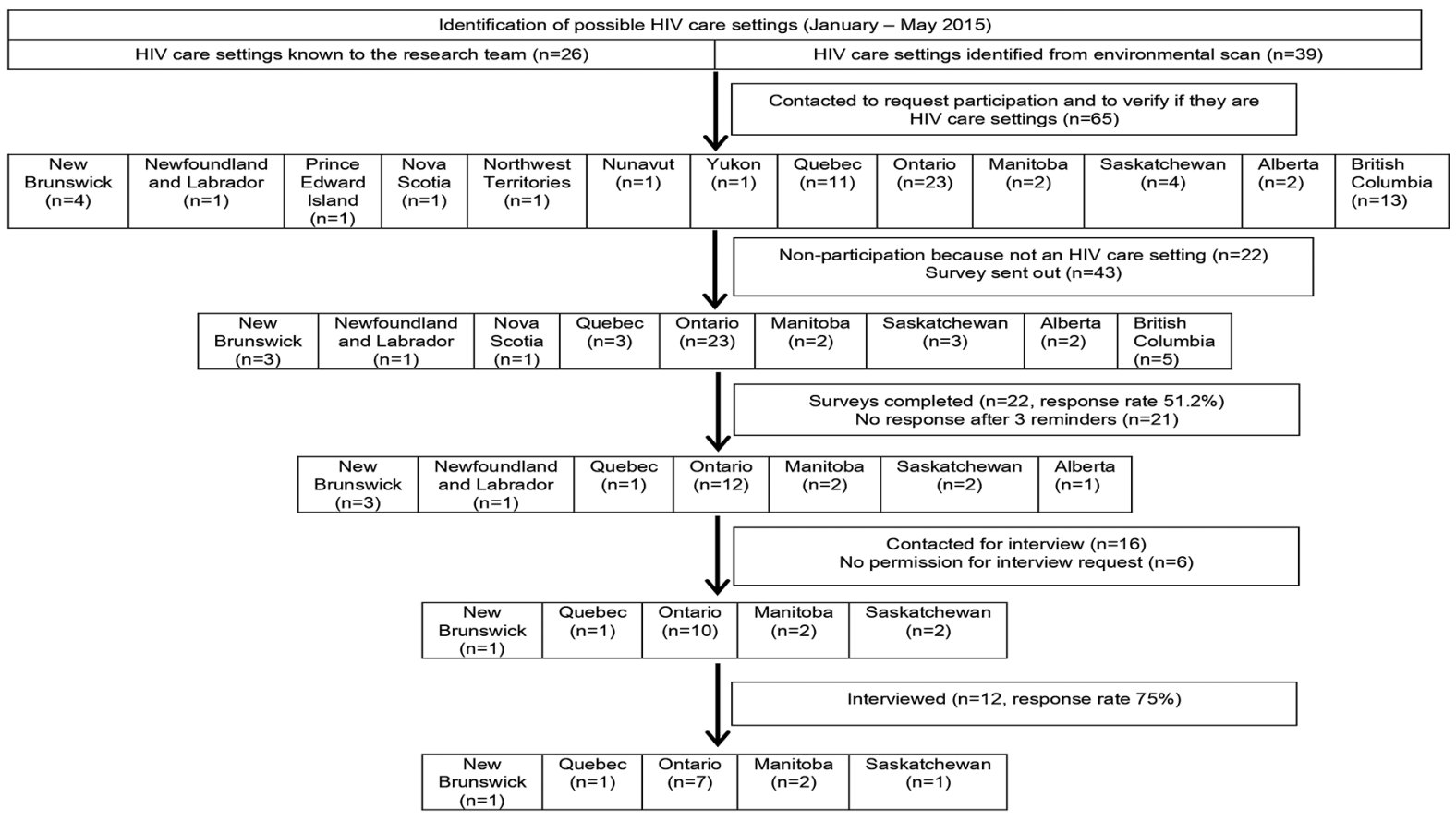




\section{Appendix B}

\section{Canadian HIV Clinic Survey}

Welcome to the Canadian HIV Clinic Survey.

The LHIV Innovation Team thanks you for your interest in this important research.

This survey will take approximately 30-45 minutes to complete. You may complete it in one or more sessions.

This survey is designed to ask questions about how your team works together in caring for persons living with HIV, but also asks for specific human resources data, such as the number of patients in your clinic (HIV and other) and number and type of practitioners.

Please review the Participant Informed Consent Form (on the next page), which provides key information about the study.

The survey consists of two parts:

- Part 1 is the Patient-Centered Medical Home Assessment (PCMH-A) that has been adapted for the Canadian HIV clinic context.

- Part 2 has questions about the organization of your clinic. This survey has been adapted in part from the Canadian Institute for Health Information's' Measuring Organizational Attributes of Primary Health Care Survey and the Primary Health Care indicator Framework developed by the LHIV Innovation Team (led by, Dr. Sharon Johnston).

Your responses will be automatically saved, and you can return to your survey at any time by clicking on the link in the original email. . When you are satisfied with your responses, click "Submit" to finalize your survey.

Thank you again for your help.

Please contact $X X X$ at $\underline{X X X}$ or toll free at $1-X X X-X X X-X X X X$ with any technical issues.

Note: This survey may not work properly on a cellular phone.

PART ONE - Patient-Centered Medical Home Assessment (PCMH-A)

- DIRECTIONS Answer each question from the perspective of one organization (e.g., a practice, clinic, hospital).

- Choose the level that best describes your organization.

- For each question, click on the point value that best describes the level of care that currently exists in your organization.

- Each question presents key aspects of patient-centred care. Each aspect is divided into four levels ( $D$ to $A$ ) showing various stages in development toward a patient-centered medical home.

- The stages are represented by points that range from 1 to 12 . The higher point values indicate that the actions described in that box are more fully implemented. 
Section 1: PATIENT ROSTERING

\begin{tabular}{|c|c|c|c|c|c|c|c|c|c|c|c|c|}
\hline Components & \multicolumn{3}{|c|}{ Level D } & \multicolumn{3}{|c|}{ Level C } & \multicolumn{3}{|c|}{ Level B } & \multicolumn{3}{|c|}{ Level A } \\
\hline 1. Patients & $\begin{array}{l}\text {...are } \\
\text { provic }\end{array}$ & sigr & ecific & $\begin{array}{l}\text {...area } \\
\text { provid } \\
\text { routine } \\
\text { admini }\end{array}$ & $\begin{array}{l}\text { atie } \\
\text { by t }\end{array}$ & $\begin{array}{l}\text { are not } \\
\text { tice for } \\
\text { poses. }\end{array}$ & $\begin{array}{l}\text {...are a } \\
\text { provide } \\
\text { routinel } \\
\text { mainly } \\
\text { purpose }\end{array}$ & du & are & \multicolumn{3}{|c|}{$\begin{array}{l}\text {...are assigned to specific } \\
\text { providers and patient data } \\
\text { are routinely used for } \\
\text { scheduling purposes and are } \\
\text { continuously monitored to } \\
\text { balance supply and demand. }\end{array}$} \\
\hline Score & 1 & 2 & 3 & 4 & 5 & 6 & 7 & 8 & 9 & 10 & 11 & 12 \\
\hline $\begin{array}{l}\text { 2. Registry or } \\
\text { patient-level } \\
\text { data }\end{array}$ & \multicolumn{3}{|c|}{$\begin{array}{l}\text {...are not available to assess } \\
\text { or manage care for practice } \\
\text { populations. }\end{array}$} & \multicolumn{3}{|c|}{$\begin{array}{l}\text {... are availableto assess and } \\
\text { manage care for practice } \\
\text { populations, but only on an } \\
\text { adhoc basis. }\end{array}$} & \multicolumn{3}{|c|}{$\begin{array}{l}\text {... are regularly available to } \\
\text { assess and manage care for } \\
\text { practice populations, but only for } \\
\text { a limited number of diseases and } \\
\text { risk states. }\end{array}$} & \multicolumn{3}{|c|}{$\begin{array}{l}\text {...are regularly available to } \\
\text { assess and manage care for } \\
\text { practice populations, across } \\
\text { a comprehensive set of } \\
\text { diseases and risk states. }\end{array}$} \\
\hline Score & 1 & 2 & 3 & 4 & 5 & 6 & 7 & 8 & 9 & 10 & 11 & 12 \\
\hline $\begin{array}{l}\text { 3. Electronic records } \\
\text { on individual } \\
\text { patients }\end{array}$ & \multicolumn{3}{|c|}{$\begin{array}{l}\text {...are not available to practice } \\
\text { teams for pre-visit planning or } \\
\text { patient outreach. }\end{array}$} & \multicolumn{3}{|c|}{$\begin{array}{l}\text {... are available to practice teams } \\
\text { but are not routinely used for pre- } \\
\text { visit planning or patient outreach. }\end{array}$} & \multicolumn{3}{|c|}{$\begin{array}{l}\text {...are available to practice teams } \\
\text { and routinely used for pre-visit } \\
\text { planning or patient outreach, but } \\
\text { only for a limited number of } \\
\text { diseases and risk states. }\end{array}$} & \multicolumn{3}{|c|}{$\begin{array}{l}\text {...are available to practice teams } \\
\text { and routinely used for pre-visit } \\
\text { planning and patient outreach, } \\
\text { across a comprehensive set of } \\
\text { diseases and risk states. }\end{array}$} \\
\hline Score & 1 & 2 & 3 & 4 & 5 & 6 & 7 & 8 & 9 & 10 & 11 & 12 \\
\hline $\begin{array}{l}\text { 4. Reports on care } \\
\text { processes or } \\
\text { outcomes of care }\end{array}$ & \multicolumn{3}{|c|}{$\begin{array}{l}\text {...are not routinely available to } \\
\text { providers. }\end{array}$} & \multicolumn{3}{|c|}{$\begin{array}{l}\text {...are routinely provided as } \\
\text { feedback to providers but not } \\
\text { reported externally. }\end{array}$} & \multicolumn{3}{|c|}{$\begin{array}{l}\text {... are routinely provided as } \\
\text { feedback to providers, and } \\
\text { reported externally (e.g. to } \\
\text { patients, other teams or external } \\
\text { agencies) but with team } \\
\text { identities masked. }\end{array}$} & \multicolumn{3}{|c|}{$\begin{array}{l}\text {...are routinely provided as } \\
\text { feedback to providers, and } \\
\text { transparently reported } \\
\text { externally to patients, other } \\
\text { teams and external agencies. }\end{array}$} \\
\hline Score & 1 & 2 & 3 & 4 & 5 & 6 & 7 & 8 & 9 & 10 & 11 & 12 \\
\hline
\end{tabular}

\section{Section 2: CONTINUOUSTEAM-BASED HEALING RELATIONSHIPS}

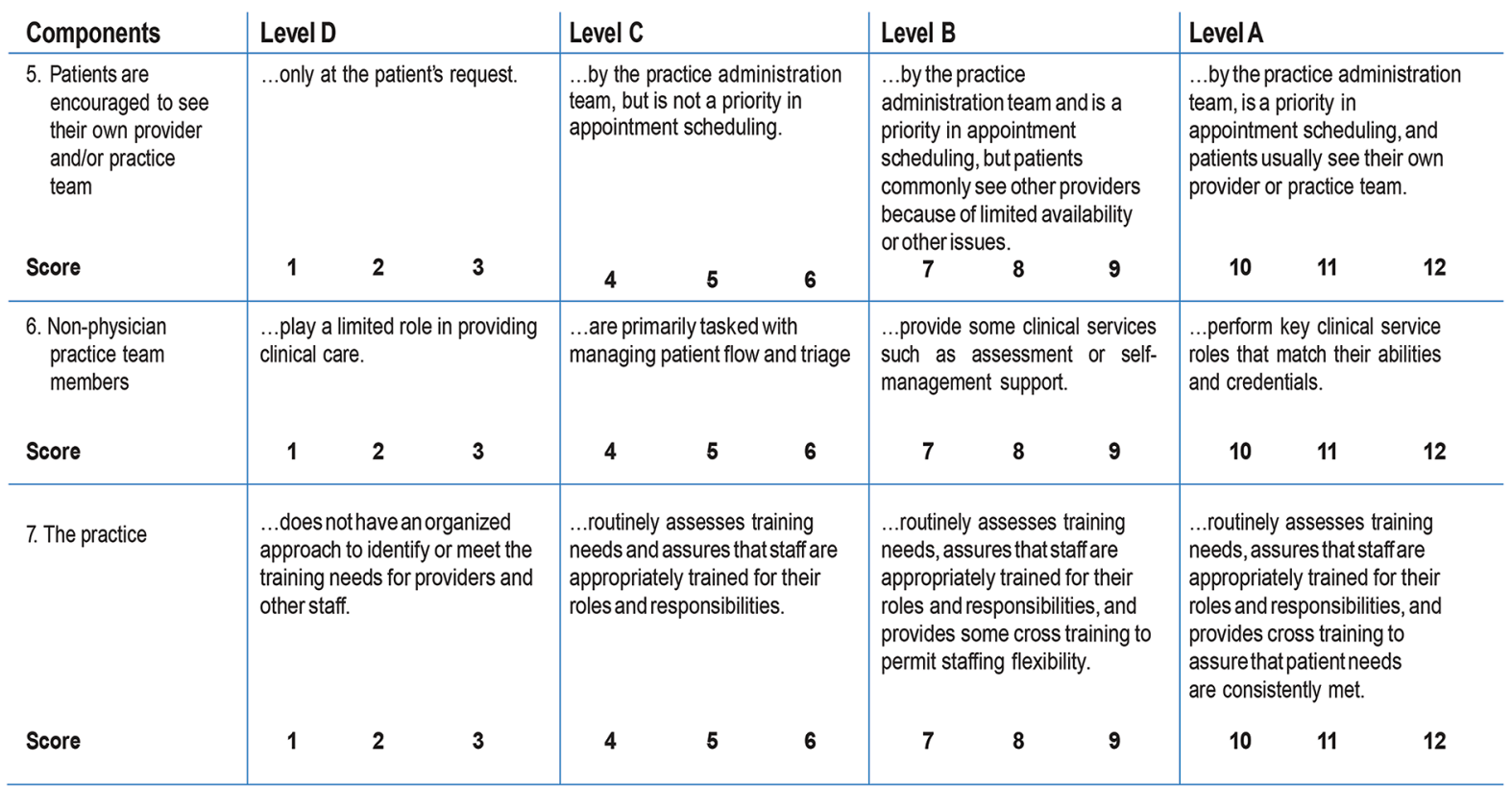


Section3: PATIENT-CENTERED INTERACTIONS

\begin{tabular}{|c|c|c|c|c|c|}
\hline Components & Level D & & Level C & Level B & Level A \\
\hline $\begin{array}{l}\text { 8. Assessing patient } \\
\text { and family values } \\
\text { and preferences }\end{array}$ & ...is not done. & & $\begin{array}{l}\text {...is done, but not used in } \\
\text { planning and organizing care. }\end{array}$ & $\begin{array}{l}\text {...is done and providers } \\
\text { incorporate it in planning and } \\
\text { organizing care on an ad } \\
\text { hoc basis. }\end{array}$ & $\begin{array}{l}\text {...is systematically done and } \\
\text { incorporated in planning and } \\
\text { organizing care. }\end{array}$ \\
\hline Score & 1 & 3 & 4 & 9 & 12 \\
\hline $\begin{array}{l}\text { 9. Involving patients in } \\
\text { decision-making and } \\
\text { care }\end{array}$ & ...is not a priority. & & $\begin{array}{l}\text {...is accomplished by provision } \\
\text { of patient education materials or } \\
\text { referrals to classes. }\end{array}$ & $\begin{array}{l}\text {...is supported and documented } \\
\text { by practice teams. }\end{array}$ & $\begin{array}{l}\text {...is systematically supported by } \\
\text { practice teams trained in decision } \\
\text { making techniques. }\end{array}$ \\
\hline Score & 1 & 3 & 4 & 9 & 12 \\
\hline $\begin{array}{l}\text { 10. Patient } \\
\text { comprehension } \\
\text { of verbal and } \\
\text { written materials }\end{array}$ & ...is not assessed. & & $\begin{array}{l}\text {...is assessed and accomplished } \\
\text { by assuring that materials are at } \\
\text { a level and language that patients } \\
\text { understand. }\end{array}$ & $\begin{array}{l}\text {...is assessed and accomplished } \\
\text { by hiring multi-lingual staff, and } \\
\text { assuring that both materials } \\
\text { and communications are at a } \\
\text { level and language that patients } \\
\text { understand. }\end{array}$ & $\begin{array}{l}\text {...is supported at an organizational } \\
\text { level by translation services, hiring } \\
\text { multi-lingual staff, and training staff } \\
\text { in health literacy and communication } \\
\text { techniques (such as closing the loop) } \\
\text { assuring that patients know what to } \\
\text { do to manage conditions at home. }\end{array}$ \\
\hline Score & 2 & 3 & 4 & 9 & 10 \\
\hline
\end{tabular}

PART 3: PATIENT-CENTERED INTERACTIONS CONTINUED ON NEXT PAGE

\section{Secion3: PATIENT-CENTERED INTERACTIONS CONTINUED}

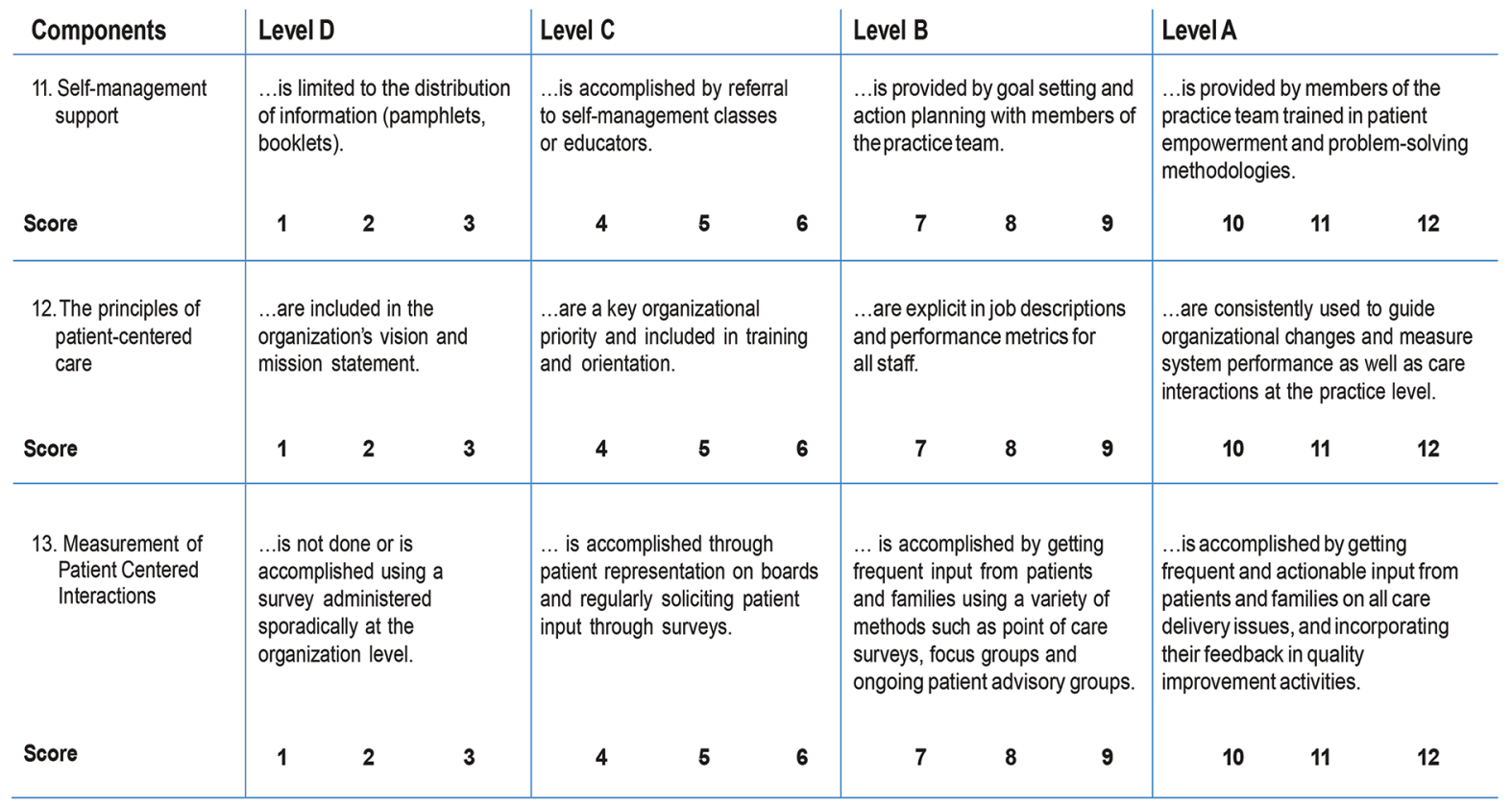


Section 4: ENGAGED LEADERSHIP

\begin{tabular}{|c|c|c|c|c|c|c|c|c|c|c|c|c|}
\hline Components & \multicolumn{3}{|c|}{ Level D } & \multicolumn{3}{|c|}{ Level C } & \multicolumn{3}{|c|}{ Level B } & \multicolumn{3}{|c|}{ LevelA } \\
\hline 14. Executive leaders & \multicolumn{3}{|c|}{$\begin{array}{l}\text {...are focused on short-term } \\
\text { business priorities. }\end{array}$} & \multicolumn{3}{|c|}{$\begin{array}{l}\text {...visibly support and create } \\
\text { an infrastructure for quality } \\
\text { improvement, but do not commit } \\
\text { resources. }\end{array}$} & \multicolumn{3}{|c|}{$\begin{array}{l}\text {...allocate resources and actively } \\
\text { reward quality improvement } \\
\text { initiatives. }\end{array}$} & \multicolumn{3}{|c|}{$\begin{array}{l}\text {...support continuous learning } \\
\text { throughout the organization, } \\
\text { review and act upon quality data, } \\
\text { and have a long-term strategy } \\
\text { and funding commitment to } \\
\text { explore, implement and spread } \\
\text { quality improvement initiatives. }\end{array}$} \\
\hline Score & 1 & 2 & 3 & 4 & 5 & 6 & 7 & 8 & 9 & 10 & 11 & 12 \\
\hline 15. Clinical leaders & \multicolumn{3}{|c|}{$\begin{array}{l}\text {...intermittently focus on } \\
\text { improving quality. }\end{array}$} & \multicolumn{3}{|c|}{$\begin{array}{l}\text {...have developed a vision for } \\
\text { quality improvement, but no } \\
\text { consistent process for } \\
\text { getting there. }\end{array}$} & \multicolumn{3}{|c|}{$\begin{array}{l}\text {...are committed to a quality } \\
\text { improvement process, and } \\
\text { sometimes engage teams } \\
\text { in implementation and } \\
\text { problem solving. }\end{array}$} & \multicolumn{3}{|c|}{$\begin{array}{l}\text {... consistently champion and } \\
\text { engage clinical teams in } \\
\text { improving patient experience } \\
\text { of care and clinical outcomes. }\end{array}$} \\
\hline Score & 1 & 2 & 3 & 4 & 5 & 6 & 7 & 8 & 9 & 10 & 11 & 12 \\
\hline $\begin{array}{l}\text { 16. The organization's } \\
\text { hiring and training } \\
\text { processes }\end{array}$ & \multicolumn{3}{|c|}{$\begin{array}{l}\text {... focus only on the narrowly } \\
\text { defined functions and } \\
\text { requirements of each position. }\end{array}$} & \multicolumn{3}{|c|}{$\begin{array}{l}\text {...reflect how potential hires will } \\
\text { affect the culture and participate } \\
\text { in quality improvement activities. }\end{array}$} & \multicolumn{3}{|c|}{$\begin{array}{l}\text {...place a priority on the ability } \\
\text { of new and existing staff to } \\
\text { improve care and create a } \\
\text { patient-centered culture. }\end{array}$} & \multicolumn{3}{|c|}{$\begin{array}{l}\text {...support and sustain } \\
\text { improvements in care through } \\
\text { training and incentives focused } \\
\text { on rewarding patient-centered } \\
\text { care. }\end{array}$} \\
\hline Score & 1 & 2 & 3 & 4 & 5 & 6 & 7 & 8 & 9 & 10 & 11 & 12 \\
\hline \multirow[t]{2}{*}{$\begin{array}{l}\text { 17. The responsibility } \\
\text { for conducting } \\
\text { quality } \\
\text { improvement } \\
\text { activities }\end{array}$} & \multicolumn{3}{|c|}{$\begin{array}{l}\text {...is not assigned by leadership } \\
\text { to any specific group. }\end{array}$} & \multicolumn{3}{|c|}{$\begin{array}{l}\text {...is assigned to a group without } \\
\text { committed resources. }\end{array}$} & \multicolumn{3}{|c|}{$\begin{array}{l}\text {...is assigned to an organized } \\
\text { quality improvement group who } \\
\text { receive dedicated resources. }\end{array}$} & \multicolumn{3}{|c|}{$\begin{array}{l}\text {...is shared by all staff, from } \\
\text { leadership to team members, } \\
\text { and is made explicit through } \\
\text { protected time to meet and } \\
\text { specific resources to engage } \\
\text { in QI. }\end{array}$} \\
\hline & 1 & 2 & 3 & 4 & 5 & 6 & 7 & 8 & 9 & 10 & 11 & 12 \\
\hline
\end{tabular}

Section 5: QUALITY IMPROVEMENT (QI) STRATEGY

\begin{tabular}{|c|c|c|c|c|c|c|c|c|c|c|c|c|}
\hline Components & \multicolumn{3}{|c|}{ Level D } & \multicolumn{3}{|c|}{ Level C } & \multicolumn{3}{|c|}{ Level B } & \multicolumn{3}{|c|}{ Level A } \\
\hline $\begin{array}{l}\text { 18. Quality improvement } \\
\text { activities }\end{array}$ & \multicolumn{3}{|c|}{$\begin{array}{l}\text {...are not organized or } \\
\text { supported consistently. }\end{array}$} & \multicolumn{3}{|c|}{$\begin{array}{l}\text {... are conducted on an ad } \\
\text { hoc basis in reaction to } \\
\text { specific problems. }\end{array}$} & \multicolumn{3}{|c|}{$\begin{array}{l}\text {...are based on a proven } \\
\text { improvement strategy in reaction } \\
\text { to specific problems. }\end{array}$} & \multicolumn{3}{|c|}{$\begin{array}{l}\text {... are based on a proven } \\
\text { improvement strategy and } \\
\text { used continuously in meeting } \\
\text { organizational goals. }\end{array}$} \\
\hline Score & 1 & 2 & 3 & 4 & 5 & 6 & 7 & 8 & 9 & 10 & 11 & 12 \\
\hline $\begin{array}{l}\text { 19. Performance } \\
\text { measures }\end{array}$ & \multicolumn{3}{|c|}{$\begin{array}{l}\text {...are not available for the } \\
\text { clinical site. }\end{array}$} & \multicolumn{3}{|c|}{$\begin{array}{l}\text {... are available for the clinical } \\
\text { site, but are limited in scope. }\end{array}$} & \multicolumn{3}{|c|}{$\begin{array}{l}\text {...are comprehensive - including } \\
\text { clinical, operational, and patient } \\
\text { experience measures - and } \\
\text { available for the practice, but not } \\
\text { for individual providers. }\end{array}$} & \multicolumn{3}{|c|}{$\begin{array}{l}\text {...are comprehensive - including } \\
\text { clinical, operational, and patient } \\
\text { experience measures - and fed } \\
\text { back to individual providers. }\end{array}$} \\
\hline Score & 1 & 2 & 3 & 4 & 5 & 6 & 7 & 8 & 9 & 10 & 11 & 12 \\
\hline $\begin{array}{l}\text { 20. Quality improvement } \\
\text { activities are } \\
\text { conducted by }\end{array}$ & \multicolumn{3}{|c|}{$\begin{array}{l}\text {... a centralized committee } \\
\text { or department. }\end{array}$} & \multicolumn{3}{|c|}{...topic specific Ql committees. } & \multicolumn{3}{|c|}{$\begin{array}{l}\text {... all practice teams supported by } \\
\text { a QI infrastructure. }\end{array}$} & \multicolumn{3}{|c|}{$\begin{array}{l}\text {...practice teams supported by } \\
\text { a Ql infrastructure with } \\
\text { meaningful involvement of } \\
\text { patients and families. }\end{array}$} \\
\hline Score & 1 & 2 & 3 & 4 & 5 & 6 & 7 & 8 & 9 & 10 & 11 & 12 \\
\hline $\begin{array}{l}\text { 21. An Electronic Health } \\
\text { Record that is } \\
\text { Meaningful-Use } \\
\text { certified }\end{array}$ & \multicolumn{3}{|c|}{$\begin{array}{l}\text {...is not present or is } \\
\text { being implemented. }\end{array}$} & \multicolumn{3}{|c|}{$\begin{array}{l}\ldots \text { is in place and is being used to } \\
\text { capture clinical data. }\end{array}$} & \multicolumn{3}{|c|}{$\begin{array}{l}\text {...is used routinely during patient } \\
\text { encounters to provide clinical } \\
\text { decision support and to share } \\
\text { data with patients. }\end{array}$} & \multicolumn{3}{|c|}{$\begin{array}{l}\ldots \text { is also used routinely to } \\
\text { support population management } \\
\text { and quality improvement efforts. }\end{array}$} \\
\hline Score & 1 & 2 & 3 & 4 & 5 & 6 & 7 & 8 & 9 & 10 & 11 & 12 \\
\hline
\end{tabular}


Section 6: ENHANCED ACCESS

\begin{tabular}{|c|c|c|c|c|c|c|c|c|c|c|c|c|}
\hline Components & \multicolumn{3}{|c|}{ Level D } & \multicolumn{3}{|c|}{ Level C } & \multicolumn{3}{|c|}{ Level B } & \multicolumn{3}{|c|}{ Level A } \\
\hline $\begin{array}{l}\text { 22. Appointment } \\
\text { systems }\end{array}$ & \multicolumn{3}{|c|}{$\begin{array}{l}\text {... are limited to a single office } \\
\text { visit type. }\end{array}$} & \multicolumn{3}{|c|}{$\begin{array}{l}\text {...provide some flexibility in } \\
\text { scheduling different visit lengths. }\end{array}$} & \multicolumn{3}{|c|}{$\begin{array}{l}\text {... provide flexibility and include } \\
\text { capacity for same day visits. }\end{array}$} & \multicolumn{3}{|c|}{$\begin{array}{l}\text {...are flexible and can } \\
\text { accommodate customized visit } \\
\text { lengths, same day visits, } \\
\text { scheduled follow-up and multiple } \\
\text { provider visits. }\end{array}$} \\
\hline Score & 1 & 2 & 3 & 4 & 5 & 6 & 7 & 8 & 9 & 10 & 11 & 12 \\
\hline $\begin{array}{l}\text { 23. Contacting the } \\
\text { practice team } \\
\text { during regular } \\
\text { business hours }\end{array}$ & \multicolumn{3}{|c|}{...is difficult. } & \multicolumn{3}{|c|}{$\begin{array}{l}\text {...relies on the practice's ability to } \\
\text { respond to telephone messages. }\end{array}$} & \multicolumn{3}{|c|}{$\begin{array}{l}\text {...is accomplished by staff } \\
\text { responding by telephone within } \\
\text { the same day. }\end{array}$} & \multicolumn{3}{|c|}{$\begin{array}{l}\text {...is accomplished by providing } \\
\text { a patient a choice between email } \\
\text { and phone interaction, utilizing } \\
\text { systems which are monitored for } \\
\text { timeliness. }\end{array}$} \\
\hline Score & 1 & 2 & 3 & 4 & 5 & 6 & 7 & 8 & 9 & 10 & 11 & 12 \\
\hline 24. After-hours access & \multicolumn{3}{|c|}{$\begin{array}{l}\text {...is not available or limited to an } \\
\text { answering machine. }\end{array}$} & \multicolumn{3}{|c|}{$\begin{array}{l}\text {....is available from a coverage } \\
\text { arrangement without a } \\
\text { standardized communication } \\
\text { protocol back to the practice } \\
\text { for urgent problems. }\end{array}$} & \multicolumn{3}{|c|}{$\begin{array}{l}\text {...is provided by coverage } \\
\text { arrangement that shares } \\
\text { necessary patient data and } \\
\text { provides a summary to } \\
\text { the practice. }\end{array}$} & \multicolumn{3}{|c|}{$\begin{array}{l}\text {...is available via the patient's } \\
\text { choice of email, phone or } \\
\text { in-person directly from the } \\
\text { practice team or a provider } \\
\text { closely in contact with the team } \\
\text { and patient information. }\end{array}$} \\
\hline Score & 1 & 2 & 3 & 4 & 5 & 6 & 7 & 8 & 9 & 10 & 11 & 12 \\
\hline
\end{tabular}

Section 7: CARE COORDINATION CONTINUED

\begin{tabular}{|c|c|c|c|c|c|c|c|c|c|c|c|c|}
\hline Components & \multicolumn{3}{|c|}{ Level D } & \multicolumn{3}{|c|}{ Level C } & \multicolumn{3}{|c|}{ Level B } & \multicolumn{3}{|c|}{ Level A } \\
\hline $\begin{array}{l}\text { 28. Follow-up by the } \\
\text { primary care } \\
\text { practice with } \\
\text { patients seen in } \\
\text { the Emergency } \\
\text { Room or hospital }\end{array}$ & \multicolumn{3}{|c|}{$\begin{array}{l}\text {...generally does not occur } \\
\text { because the information is } \\
\text { not available to the primary } \\
\text { care team. }\end{array}$} & \multicolumn{3}{|c|}{$\begin{array}{l}\text {...occurs only if the ER or hospital } \\
\text { alerts the primary care practice. }\end{array}$} & \multicolumn{3}{|c|}{$\begin{array}{l}\text {...occurs because the primary } \\
\text { care practice makes proactive } \\
\text { efforts to identify patients. }\end{array}$} & \multicolumn{3}{|c|}{$\begin{array}{l}\text {...is done routinely because } \\
\text { the primary care practice has } \\
\text { arrangements in place with the } \\
\text { ER and hospital to both track } \\
\text { these patients and ensure that } \\
\text { follow-up is completed within } \\
\text { a few days. }\end{array}$} \\
\hline Score & 1 & 2 & 3 & 4 & 5 & 6 & 7 & 8 & 9 & 10 & 11 & 12 \\
\hline $\begin{array}{l}\text { 29. Linking patients } \\
\text { to supportive } \\
\text { community- } \\
\text { based resources }\end{array}$ & \multicolumn{3}{|c|}{...is not done systematically. } & \multicolumn{3}{|c|}{$\begin{array}{l}\text {...is limited to providing patients } \\
\text { a list of identified community } \\
\text { resources in an accessible } \\
\text { format. }\end{array}$} & \multicolumn{3}{|c|}{$\begin{array}{l}\text {...is accomplished through a } \\
\text { designated staff person or } \\
\text { resource responsible for } \\
\text { connecting patients with } \\
\text { community resources. }\end{array}$} & \multicolumn{3}{|c|}{$\begin{array}{l}\text {...is accomplished through } \\
\text { active coordination between } \\
\text { the health system, community } \\
\text { service agencies and patients } \\
\text { and accomplished by a } \\
\text { designated staff person. }\end{array}$} \\
\hline Score & 1 & 2 & 3 & 4 & 5 & 6 & 7 & 8 & 9 & 10 & 11 & 12 \\
\hline $\begin{array}{l}\text { 30. Test result and } \\
\text { care plans }\end{array}$ & \multicolumn{3}{|c|}{$\begin{array}{l}\text {...arenotcommunicated } \\
\text { to patients. }\end{array}$} & \multicolumn{3}{|c|}{$\begin{array}{l}\text {...are communicated to patients } \\
\text { based on an ad hoc approach. }\end{array}$} & \multicolumn{3}{|c|}{$\begin{array}{l}\text {...are systematically } \\
\text { communicated to patients in } \\
\text { a way that is convenient to } \\
\text { the practice. }\end{array}$} & \multicolumn{3}{|c|}{$\begin{array}{l}\text {...are systematically } \\
\text { communicated to patients in } \\
\text { a variety ways that are } \\
\text { convenient to patients. }\end{array}$} \\
\hline Score & 1 & 2 & 3 & 4 & 5 & 6 & 7 & 8 & 9 & 10 & 11 & 12 \\
\hline
\end{tabular}


Section 7: CARE COORDINATION CONTINUED

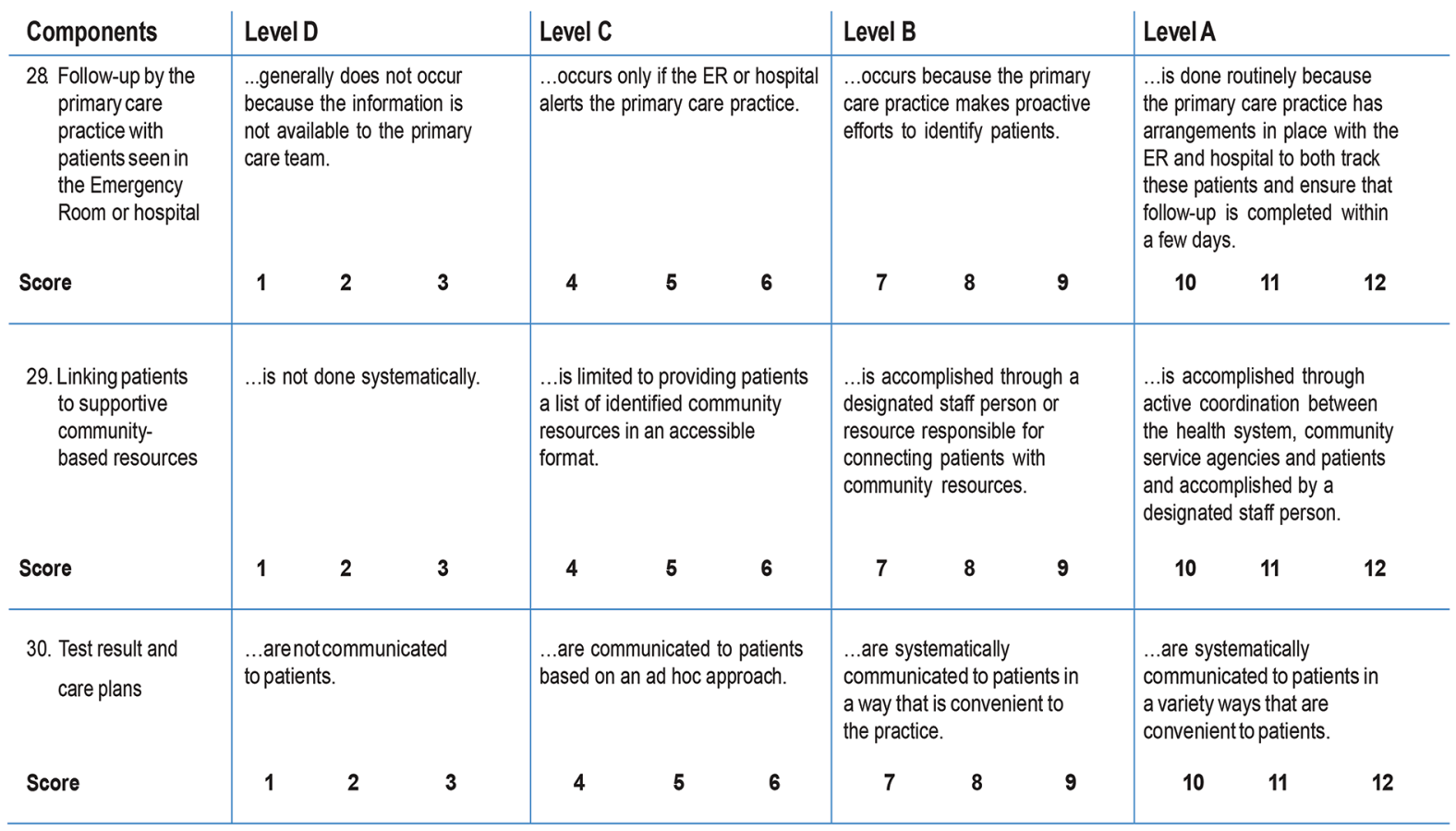

Section 8: ORGANIZED, EVIDENCE-BASED CARE

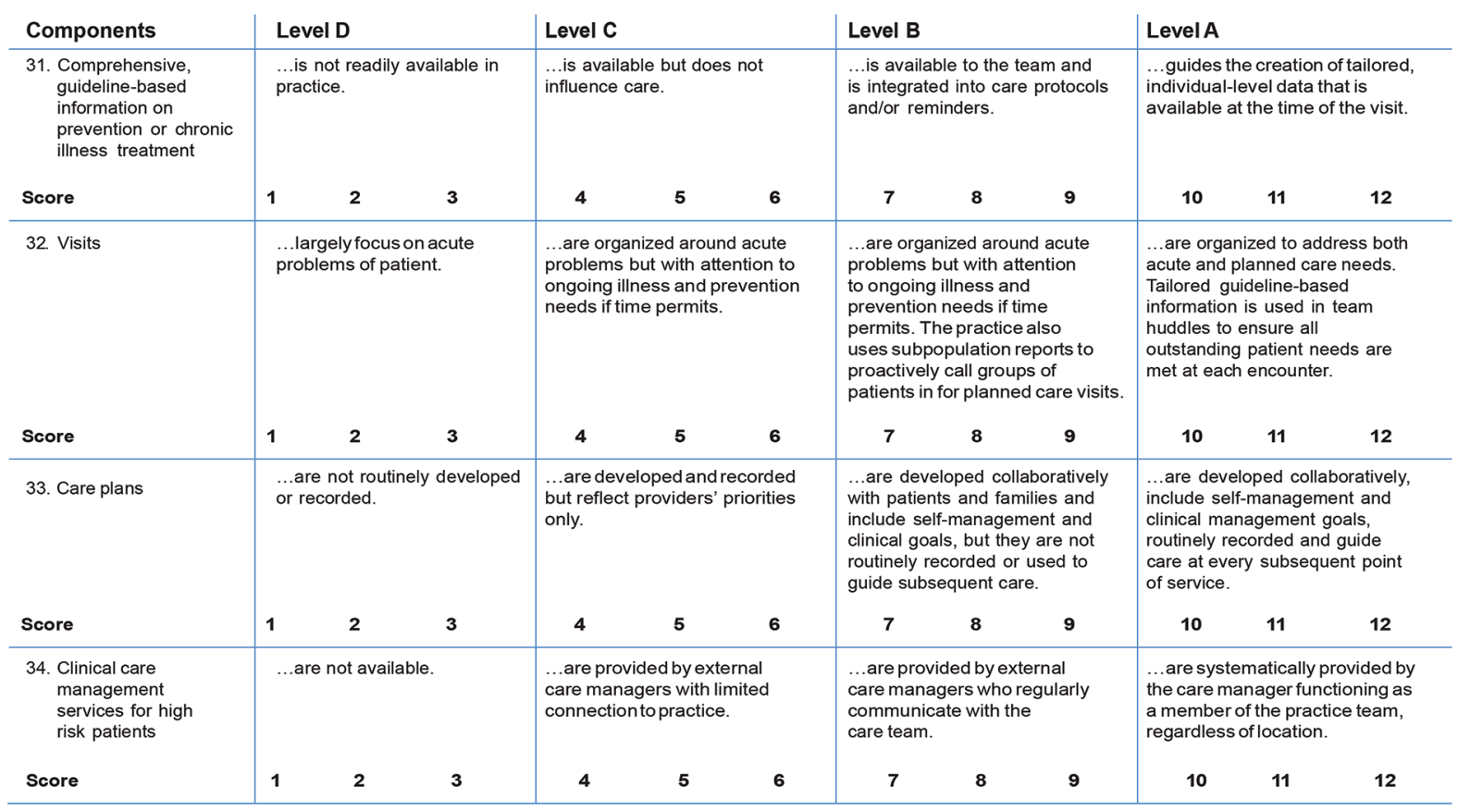




\section{Canadian HIV Clinic Survey Part Two}

In this part of the survey, we are asking questions to understand specific ways that your clinic is organized. Please provide as much information as you can.

Choose one answer per question, unless otherwise indicated.

\section{Section One: Population Served}

1. Which statement best represents the population that your clinic serves? Please choose one answer.

$\square$ Any person living with HIV

$\square$ Members of a specific HIV population (i.e. women, MSM)

$\square$ Infected children under the age of 16

$\square$ Service includes family members of persons living with HIV

$\square$ No restriction based on population

2. How many patients are registered at your clinic? Please provide your best estimate.

3. Of all the patients you serve, how many have HIV? Please provide your best estimate.

4. Are there any comments you would like to make about the population your clinic serves? 


\section{Section Two: Clinic Attributes}

1. Please identify the type of practitioners working at your clinic. Please estimate the amount of time in Full-Time Equivalent (FTE) hours each group is working each week.

Note: For each practioner type, the total FTE should not be higher than the total number of people who hold that position.

If you do not have a certain type of practioner working in your clinic please select "Not Applicable".

\begin{tabular}{l|l|l|l}
\hline Type of Practitioner & $\begin{array}{l}\text { Not } \\
\text { Applicable }\end{array}$ & $\begin{array}{l}\text { How many of each } \\
\text { practitioner type work in } \\
\text { your clinic? }\end{array}$ & $\begin{array}{l}\text { What is the total FTE in } \\
\text { your clinic for each } \\
\text { practitioner type? } \\
\text { (Note: 1.0 FTE = 35 hours } \\
\text { per week or more) }\end{array}$ \\
\hline Family physician & & & \\
\hline Nurse practitioner & & & \\
\hline Registered nurse & & & \\
\hline Physician assistant & & & \\
\hline $\begin{array}{l}\text { Specialist physician } \\
\text { (infectious disease) }\end{array}$ & & & \\
\hline $\begin{array}{l}\text { Specialist physician } \\
\text { (other) }\end{array}$ & & & \\
\hline Psychiatrist & & & \\
\hline Psychologist & & & \\
\hline Pharmacist & & & \\
\hline Addictions counsellor & & & \\
\hline Social Worker & & & \\
\hline Peer support worker & & & \\
\hline Dietitian & & & \\
\hline Home care support & & & \\
\hline person & & & \\
\hline Dental care worker & & & \\
\hline Occupational or \\
Physiotherapist & & & \\
\hline Rehabilitation service \\
worker & & & \\
\hline $\begin{array}{l}\text { Smoking cessation } \\
\text { support worker }\end{array}$ & & & \\
\hline Clerical staff & & & \\
\hline Non-clinical managers & & & \\
\hline Other (please specify) & & & \\
\hline
\end{tabular}

Are there any comments you would like to make about the types of practioners at your clinic? 


\section{Section Three: Clinic Services Offered}

1. For persons living with HIV that you serve, which of the following clinical tests and services are available on site?

\begin{tabular}{l|l|l}
\hline Tests/lmmunizations & Yes & No \\
\hline Routine blood work & & \\
\hline Routine HIV blood work (CD4, VL) & & \\
\hline HIV resistance testing & & \\
\hline Rapid streptococcal test (strep test) & & \\
\hline Cervical smear (pap test) & & \\
\hline Routine immunizations & & \\
\hline Influenza (seasonal flu) vaccination & & \\
\hline Pregnancy test & & \\
\hline Urinalysis & & \\
\hline Mantoux (TB) skin testing & & \\
\hline Sexually transmitted infection testing & & \\
\hline Spot glucose testing (glucoscan) & & \\
\hline Services/Procedures & & \\
\hline Needle exchange & & \\
\hline Suture/minor surgery & & \\
\hline Musculoskeletal injection/aspiration & & \\
\hline IUD insertion & & \\
\hline Chronic disease self-management program & \\
\hline Established process and resources to follow up on patients who miss & & \\
appointments & & \\
\hline
\end{tabular}

Are there any comments you would like to make about the clinic tests and services available at your clinic? 


\section{Section Four: Technical Resources}

1. In your clinic, do you have an electronic medical record system?

$\square$ Yes $\square$ Planned, but not yet implemented $\square$ Not Sure $\square$ No

If yes or planned:

Which EMR system do you use?

Are there any comments you would like to make about using an EMR system?

2. In your clinic, do you use?

\begin{tabular}{l|l|l|l|l}
\hline & Yes & No & Planned & $\begin{array}{c}\text { Not } \\
\text { sure }\end{array}$ \\
\hline Internet access for all staff & & & & \\
\hline $\begin{array}{l}\text { Computerized tools to aid medical decision-making } \\
\text { (computerized alerts and recalls, integration of } \\
\text { clinical practice guidelines) }\end{array}$ & & & & \\
\hline $\begin{array}{l}\text { Electronic interface to diagnostic imaging \& } \\
\text { laboratory services }\end{array}$ & & & & \\
\hline $\begin{array}{l}\text { An electronic system to transmit prescriptions to } \\
\text { pharmacies }\end{array}$ & & & & \\
\hline $\begin{array}{l}\text { A web-based appointment system for patients to } \\
\text { book appointments }\end{array}$ & & & & \\
\hline Information technology support (on site or on call) & & & & \\
\hline Computer software to manage appointments & & & & \\
\hline $\begin{array}{l}\text { Unique email addresses for the clinic (i.e. } \\
\text { name@myclinic.ca) }\end{array}$ & & & & \\
\hline $\begin{array}{l}\text { Automated option to send appointment reminders } \\
\text { to patients }\end{array}$ & & & & \\
\hline
\end{tabular}

Are there any comments you would like to make about the technical resources in your clinic? 


\section{Section Five: About you and your Clinic}

1. How would you characterize the locale for your clinic?
$\square$ City
$\square$ Suburb
$\square$ Small town
$\square$ Rural

2. Where is your clinic located?

$\square$ In a building owned by the physicians or of which they are shareholders

$\square$ In rented offices in a commercial building for health professionals

$\square$ In rented offices in a commercial building for any type of business

$\square$ In an establishment that is part of the publicly funded health network (hospital, etc.) or university

$\square$ Other (please specify):

3. What type of physical locations are considered as part of your clinic?

One physical location

$\square$ One physical location but linked to affiliated or satellite sites

More than one location, but each location is managed independently

$\square$ More than one location with coordination of care and administrative activities between sites

4. What funding arrangement best describes the payment model for physicians in your clinic?

Fee-for-service

Capitation or roster

Salary (hourly rate, sessional payment, contract)

Blended model (mix of different payment models)

$\square$ Other (please specify):

5. Does your clinic receive other types of funding from:

\begin{tabular}{l|c|c}
\hline & Yes & No \\
\hline Targeted program/activity funding/grants & & \\
\hline Targeted staffing funding/grants & & \\
\hline Performance-based financial incentives & & \\
\hline Academic research grants & & \\
\hline Other (please specify): & & \\
\hline
\end{tabular}

Are there any comments you would like to make about your clinic location or funding?

Briefly describe the process you used for parts 1 and 2 to fill out the survey (e.g., each team member filled out a separate form and reached consensus in a face-to-face meeting; filled out by the team leader in consultation with other team members as needed). 
On behalf of the LHIV Innovation Team, we want to thank you for taking the time to complete this important survey.

With your help and insights, we hope to make important recommendations to improve care for people living with HIV.

\section{Additional Request}

We may wish to conduct confidential interviews with you or members of your team after the survey analysis is complete. The purpose of these interviews would be to better understand approaches to the changes needed in caring for persons living with HIV.

\section{Online Instructions}

If you choose to provide your contact information, click on the link that appears. If you select Yes, you will be directed to a new page. By clicking on the link you will not lose any of the information that you have already entered into the survey. Once you have completed the contact form, please make sure you return to submit the survey.

The information you provide on this contact form and during any follow-up interviews will not be linked to the survey responses already provided.

If you do not wish to provide your contact information, simply select No below.

Do you give your permission for us to contact you for separate, confidential interviews if needed?

$$
\square \text { Yes } \square \text { No }
$$

If they choose yes, there will be a link here with a pop up or automatic email (depending on the survey platform's capacity) that will direct them to answer these questions in a separate document or an automatic email will be sent asking them to complete a form with this information to be returned to the research team.

Please contact Lois Crowe at Icrowe@bruyere.org or toll free at 1-855-561-6891 if you have any questions about the survey administration or technical issues.

\section{Thank you!}

Please press SUBMIT when you are satisfied with your answers.

Paper Instructions

If you choose to provide your contact information, please complete the separate Permission to Contact Form. If you choose not to provide your information, you do not need to complete the form.

The Permission to Contact Form is a separate page that will not be kept with your survey results, so the information you provide on this contact form and during any follow-up interviews will not be linked to the survey responses.

Alternatively, please first copy and paste the following table into an email, then fill in your contact information and send it to lcrowe@bruyere.org. 


\section{Permission to Contact Form}

\section{STUDY TITLE}

A mixed methods study to characterize the organizational attributes and patient-centred medical home features of HIV care settings in Canada. (OHSN \#20140649-01H, Bruyère \#M16-15-011)

Thank you for agreeing to be contacted for separate and confidential interviews.

Please tell us the best way to contact you. Please note that the information you provide will be kept confidential and that your name or the clinic name will never be released in any report or publication. Any contact information you provide will not be linked to your survey responses.

*Indicates a Required Field

Clinic Name:

Clinic Address:

Main Clinic Location (street address, city, province, postal code):

*Your Name (the name of the person completing the survey):

Your position in the clinic:

Your phone number:

Your alternate phone number:

Your fax number:

*Your email address:

*I prefer to be contacted by $\square$ phone $\square$ email $\square$ fax 


\section{Appendix C}

\section{Interview Guide Questions}

\section{Study Title}

A mixed methods study to characterize the organizational attributes and patient-centred medical home features of HIV care settings in Canada

\section{Research Question}

What are the organizational attributes of HIV clinics in Canada?

\section{INTERVIEW SCRIPT/GUIDE}

\section{Introduction}

You are being invited to participate in a 1 hour telephone interview because you are a member of a clinic team that cares for persons living with HIV, and you provided your contact information in the event that we wanted to explore in more detail the answers you gave in the online survey you completed last summer/fall/winter.

Participation in this telephone interview is voluntary. You can still choose not to participate without affecting your current or future employment. The same privacy protections that were in place during your participation the survey portion of the study apply to this interview; all interview data will be coded with your unique study number and will not contain any information that identifies you. You will be compensated $\$ 75$ for your participation in this telephone interview.

Below is the Telephone Interview Script that will be used. We are sending this to you now so you have time to think about the discussion topics. You will be contacted in the coming weeks. If you do not wish to participate in the Telephone Interview simply let us know by replying to this e-mail.

The choice of interviewer will be determined before interview guide is sent out. There will be one interviewer per person.

\section{Interviewer \#1}

My name is [Name] and I will be the person who will interview you. I am a [Job Title] with the "Advancing Primary Health Care for Persons Living with HIV" Innovations Team. If you have any questions, please do not hesitate to contact me at 1-855-561-6891 (toll free) or by email at[Email Address].

Please note that we will be recording this interview. After the interview is over, we will transcribe the session so the conversation can be analyzed using a special software package (NVivo version 10 or 11). The recordings will be kept for 10 years after study completion. The recording will be stored on the secure server at Bruyère Continuing Care, a hospital in Ottawa. Only the research staff directly involved in the research and the transcriptionist will have access to the recording. You will not be identified by name in any report or publication arising from this interview.

Your perspective in understanding how HIV care is delivered in Canada and how your clinic provides this care is important. There are no right or wrong answers. Although we have prepared a few questions to 
lead the discussion, we would like to have an open, informal process so we can follow up on different

directions the conversation might take.

\section{Background}

Sixty-five thousand Canadians live with HIV and this prevalence is increasing as people being treated live full life spans. In Canada, HIV has been managed largely by specialists and providers in HIV-focused practice rather than by general primary care providers.

Advances in treatment have brought new challenges: diseases of aging such as diabetes, cardiovascular disease, and cancer are now common among people living with HIV. The way that HIV care has been organized and delivered in Canada may no longer meet the needs of this population.

Our team has been awarded 2.5 million dollars from the Canadian Institutes of Health Research. The goal of this program of research is to develop strategies to improve the chronic disease management of persons living with HIV.

The focus of this interview is to better understand the answers given in the first part of the survey you completed, which was the Patient-Centred Medical Home (PCMH) survey developed in the United States and adapted for the Canadian HIV clinic context. This survey was developed to help systems and provider practices move toward the "state-of-the-art" in delivering patient-centered care in the context of a medical home. The PCMH-Assessment queries clinics on their capacity in the following areas: patient rostering, team-based relationships, patient-centered interactions, team leadership and quality improvement strategy, patient access, coordination of care and use of organized and evidence-based care.

Do you have any questions before we begin?

\section{Questions}

1. Can you tell me a little bit more about your role in the clinic? How active are you in providing care to persons living with HIV?

2. The on-line survey we conducted asked a number of questions about your clinic's ability to provide patient-centred care. We know that patient-centred care means different things to different people, and we are interested in how you would describe what patient-centred care means to you?

a. For patients, it might mean that they are treated as a whole person, and that the care they receive reflects their values and preferences.

b. Clinicians may view patient-centredness as advocating for their patients to ensure their health care needs are met.

c. Clinics and health care organizations might describe themselves as providing patient-centred care when they include patients in their decision-making, and use the results of patient surveys to inform their decisions. 
d. Policy makers sometimes describe patient-centredness as a measure of health system performance or as a principle to strive for when designing health services within the budgets they have been allocated.

e. Public health practitioners may feel that patient-centredness should be less concerned with meeting the desires of individual patients and more concerned with addressing the social determinants of health, which they argue would prevent many citizens from becoming patients in the first place.

Source: http://healthydebate.ca/opinions/patient-centred-mean-achievable

3. Can you tell us about how your clinic approaches patient-centred care? Would you mind sharing some examples?

4. A patient with stable HIV comes into your clinic to meet with a physician or team member. Can you describe what services are available? What are some of the strategies you and your team use to help your patients access necessary services? Can you share some examples?

a. How do you ensure they have access to up-to-date pharmacy advice, or provide support for acquiring medications that are too expensive for them?

b. How do you link them with primary health care/specialty care for their other co-morbid conditions, such as diabetes or other chronic health disease?

c. How would they access mental health services, or peer counselling support programs?

d. Do you offer any on-site or access to community-based chronic disease self-management programs?

e. How do you support sub-populations of people with HIV (i.e. low-income, women, refugees/immigrants), to navigate the different services?

f. Do you have any specific protocols in place to support patient privacy, particularly for someone living with HIV, given the significant stigma attached to this disease?

5. What is the role of senior managers or leaders in building effective team-functioning in your clinic?

a. How are care/administrative decisions made in your clinic?

b. If these leaders were more engaged on a day-to-day basis, how might this affect functioning in the clinic?

c. How could the role of management be improved?

6. If you could set up a patient-centred care system for people living with stable HIV, what would it look like? How would your clinic need to change?

We will be publishing the results of this study in scientific journals and will present the results in different places such as presentations at scientific conferences, postings on our website (www.lhiv.ca), and sharing results with our partners. We are asking everyone who participates in these interviews if you would like the opportunity to review or comment on the findings before they are published. Are you interested?

Thank you for agreeing to speak with our team. Your perspectives will help shape the recommendations we make to decision-makers about the best way to provide care to persons living with stable HIV. 